TEACHING : Jurnal Inovasi Keguruan dan IImu Pendidikan

Vol. 1. No. 4 Desember 2021 e-ISSN : 2775-7188 | p-ISSN : 2775-717X

\title{
PENGARUH PENGETAHUAN AWAL DAN TES FORMATIF TERTULIS BERBASIS WEBSITE TERHADAP HASIL BELAJAR FISIKA SISWA MTs NEGERI BATAM
}

\author{
JURAHMIN \\ MTsN Kota Batam \\ e-mail: ccchusnul@gmail.com
}

\begin{abstract}
ABSTRAK
Penelitian ini bertujuan untuk mengetahui: (1) Perbedaan hasil belajar fisika antara siswa yang diberikan tes formatif tertulis berbasis website dengan siswa yang diberikan tes formatif tertulis berbasis paper and pencil; (2) Pengaruh interaksi antara tes formatif tertulis berbasis website, tes formatif tertulis berbasis paper and pencil, dan tingkat pengetahuan awal terhadap hasil belajar fisika; (3) Perbedaan hasil belajar fisika antara siswa yang diberikan tes formatif tertulis berbasis website dan tes formatif tertulis berbasis paper and pencil pada kelompok siswa yang memiliki tingkat pengetahuan awal tinggi; dan (4) Perbedaan hasil belajar fisika antara siswa yang diberikan tes formatif tertulis berbasis website dan tes formatif tertulis berbasis paper and pencil pada kelompok siswa yang memiliki tingkat pengetahuan awal rendah. Penelitian ini menggunakan metode eksperimen dengan desain treatment by level fixed model. Populasi seluruh kelas VIII MTsN Batam tahun pelajaran 2010/2011 sebanyak 10 kelas. Sampel penelitian ditentukan secara multi stage random sampling terdiri 4 kelas. Dua kelas eksperimen 1 diberi perlakuan tes formatif tertulis berbasis website dan dua kelas eksperimen 2 diberikan perlakuan tes formatif tertulis berbasis paper and pencil. Masing masing perlakuan terdiri dari 40 siswa. Teknik pengumpulan data pengetahuan awal dan data hasil belajar dilakukan dengan tes. Uji persyaratan analisis dilakukan dengan uji normalitas dan uji homogenitas. Uji hipotesis penelitian menggunakan anava dua jalan dan dilakukan uji lanjut dengan uji Tukey. Berdasarkan hasil analisa data disimpulkan: (1) Secara keseluruhan, hasil belajar siswa yang diberikan tes formatif tertulis berbasis website lebih tinggi dibanding siswa yang diberikan tes formatif tertulis berbasis paper and pencil; (2) Terdapat pengaruh interaksi antara tes formatif tertulis dan tingkat pengetahuan awal terhadap hasil belajar fisika; (3) Secara keseluruhan, pada kelompok siswa yang memiliki tingkat pengetahuan awal tinggi, hasil belajar siswa yang diberikan tes formatif tertulis berbasis website lebih tinggi dari siswa yang diberikan tes formatif tertulis berbasis paper and pencil; dan (4) Secara keseluruhan, pada kelompok siswa yang memiliki tingkat pengetahuan awal rendah, hasil belajar siswa yang diberikan tes formatif tertulis berbasis paper and pencil lebih tinggi dari siswa yang diberikan tes formatif tertulis berbasis website.
\end{abstract}

Kata Kunci: tes formatif tertulis berbasis website, tes formatif tertulis berbasis paper and pencil, tingkat pengetahuan awal fisika, hasil belajar fisika.

\section{ABSTRACT}

This study aims to determine: (1) Differences in physics learning outcomes between students who are given a website-based formative written test and students who are given a paper and pencil-based formative written test; (2) The effect of the interaction between a website-based formative written test and a written formative test based on a website, paper and pencil, and the level of initial knowledge of physics learning outcomes; (3) The difference in physics learning outcomes between students who were given a website-based formative written test and a paper and pencil-based formative written test in a group of students who had a high level of initial knowledge; and (4) Differences in physics learning outcomes between students who were given a website-based formative written test and a paper and pencil-based written formative test in a group of students who had a low level of initial knowledge. This research uses experimental method with treatment by level fixed model design. The population of the entire class VIII of MTsN Batam for the academic year 2010/2011 is 10 classes. The research sample was 
determined by multi-stage random sampling consisting of 4 classes. Two experimental classes 1 were given a website-based formative written test and two experimental classes 2 were given a paper and pencil-based written formative test. Each treatment consisted of 40 students. The technique of collecting initial knowledge data and learning outcomes data is done by testing. Test requirements analysis was carried out with normality test and homogeneity test. The research hypothesis was tested using two-way ANOVA and further tests were carried out with the Tukey test. Based on the results of data analysis, it can be concluded: (1) Overall, the learning outcomes of students who are given a written formative test based on a website are higher than students who are given a written formative test based on paper and pencil; (2) There is an interaction effect between written formative tests and the level of initial knowledge. on physics learning outcomes; (3) Overall, in the group of students who have a high level of initial knowledge, the learning outcomes of students who are given a website-based formative written test are higher than students who are given a paper and pencil-based written formative test; and (4) Generally Overall, in the group of students who have a low level of prior knowledge, the learning outcomes of students who are given a paper and pencil-based formative written test are higher than students who are given a website-based formative written test.

Keywords: website-based formative written test, paper and pencil-based formative written test, level of prior knowledge of physics, learning outcomes of physics.

\section{PENDAHULUAN}

Dalam evaluasi pendidikan, ada empat komponen yang saling terkait dan merupakan satu kesatuan yang tidak terpisahkan yakni evaluasi, penilaian, pengukuran, tes dan non tes. Evaluasi merupakan suatu proses penetapan nilai tentang kinerja dan hasil belajar siswa berdasarkan informasi yang diperoleh melalui penilaian. Sedangkan penilaian sebagai suatu proses pengumpulan informasi atau data yang digunakan untuk membuat keputusan tentang pembelajaran. Pembelajaran yang dimaksud mencakup siswa, kurikulum, program dan kebijakan. Evaluasi pembelajaran pada dasarnya bukan hanya menilai hasil belajar, tetapi juga proses-proses yang dilalui pendidik dan peserta didik dalam keseluruhan proses pembelajaran (Asrul, et al, 2010). Pengukuran sebagai prosedur penetapan angka-angka dengan cara yang sistematis untuk menyatakan karakteristik atau atribut individu yang bisa berupa kemampuan kognitif, afektif, psikomotorik dan kemampuan emosi serta kemampuan pengendalian emosi. Proses pengukuran dalam bidang pendidikan berkenaan dengan bagiamana mengkonstruksi, mengadministrasi, dan menskor tes (Djaali, et al., 2008). Tes sebagai suatu instrumen atau prosedur sistematis untuk mengamati dan menggambarkan satu atau lebih karakteristik siswa dengan menggunakan skala numerik atau skema klasifikasi (non tes). Di sekolah, tes biasanya merupakan suatu rangkaian pertanyaan yang harus dijawab oleh siswa dan hasilnya berupa skala numerik. Sementara skema klasifikasi (non tes) biasanya berupa prosedur observasi, wawancara, angket dan jenis non tes lainnya. Evaluasi, penilaian, pengukuran tes dan non tes bersifat hirarki. Tes dan non tes merupakan seperangkat pertanyaan atau pernyataan terbuka atau tertutup yang harus dijawab. Pengukuran membandingkan hasil pengamatan dengan kriteria. Penilaian menjelaskan dan menafsirkan hasil pengukuran. Sementara evaluasi sebagai penetapan nilai atau implikasi suatu perilaku. Dengan demikian kegiatan evaluasi melibatkan pengukuran dan asesmen. Undang-Undang Nomor 20 tahun 2003 tentang Sistem Pendidikan Nasional BAB II Pasal 3 berbunyi: "Pendidikan nasional berfungsi mengembangkan kemampuan dan membentuk watak serta peradaban bangsa yang bermartabat dalam rangka mencerdaskan kehidupan bangsa, bertujuan untuk berkembangnya potensi agar manjadi manusia yang beriman dan bertaqwa kepada Tuhan Yang Maha Esa, berakhlak mulia, sehat, berilmu, cakap, kreatif, mandiri, dan menjadi warga negara yang demokratis dan bertanggung jawab". Untuk mencapai tujuan tersebut tidaklah mudah, karena tantangan yang lebih besar dalam berbagai aspek kehidupan. Globalisasi sebagai dampak revolusi teknologi informasi dan komunikasi (TIK) mengakibatkan perubahan besar dalam berbagai aspek kehidupan. Perubahan yang paling cepat dirasakan adalah perubahan ekonomi dan pengetahuan. 
Perkembangan teknologi informasi dan komunikasi yang begitu pesat digunakan dalam berbagai disiplin ilmu, termasuk di dunia pendidikan. Perkembangan pemanfaatan teknologi informasi dan komunikasi dalam dunia pendidikan saat ini sudah tidak bisa ditawar lagi karena telah menyatu dengan perkembangan setiap aktivitas kehidupan, tidak terkecuali dalam dunia pendidikan. Demikian halnya guru sebagai tenaga profesional, harus mampu mengimbangi laju perubahan tersebut. Sikap yang harus direfleksikan oleh guru diantaranya melalui apresiasi, inovasi dan kreasi untuk memanfaatkan TIK seperti yang dinyatakan dalam Peraturan Menteri Pendidikan Nasional Nomor 16 Tahun 2007 tentang Standar Kualifikasi Akademik dan Kompetensi Guru. Berdasarkan kegiatan prasurvei yang peneliti lakukan di MTs Negeri Batam, ditemukan bahwa MTs tersebut telah memiliki fasilitas TIK yang cukup lengkap. Diantaranya, telah tersedia laboratorium komputer dan telah memiliki website (http://www.mtsnbatam.com). Namun pemanfaatan TIK (baik hardware maupun software) oleh guru-guru di satuan pendidikan itu masih cukup terbatas. TIK lebih banyak dimanfaatkan terbatas pada fungsi administratif, media atau alat bantu pembelajaran. Sedangkan pemanfaatan TIK untuk penilaian masih belum tereksplorasi secara mendalam, apalagi pemanfaatan berbagai fasilitas dan aplikasi yang ada. Salah satu yang sudah mulai diterapkan dalam penilaian hasil belajar oleh guru mata pelajaran di satuan pendidikan itu adalah pemanfaatan microsoft excel (Ms. Excel) aplikasi bagian microsoft office. Sedangkan penilaian dengan menggunakan website belum pernah dilaksanakan.

Selama ini pelaksanaan tes formatif yang dilakukan oleh guru mata pelajaran di MTs Negeri Batam masih berupa tes tertulis yang berbentuk soal pilihan ganda, soal dua pilihan jawaban (benar-salah), soal menjodohkan, soal isian, soal jawaban singkat, soal uraian, dan atau kombinasinya. Setelah tes formatif selesai dijawab oleh siswa sesuai dengan waktu yang telah ditentukan, maka siswa diwajibkan untuk mengumpulkan lembar jawaban yang telah diisi kepada guru mata pelajaran yang bersangkutan atau pengawas ujian. Selanjutnya guru melakukan pemeriksaan hasil formatif siswa dan mengembalikan lembar jawaban tes formatif kepada siswa pada pertemuan / jadwal tatap muka berikutnya. Proses seperti ini kurang efektif dan kurang efisien, karena dari proses pengumpulan lembar jawaban formatif, pemeriksaan hasil tes formatif oleh guru mata pelajaran serta pengembalian lembar jawaban tes formatif kepada siswa memerlukan waktu yang cukup lama yaitu pada jadwal tatap muka pelajaran berikutnya. Dengan kondisi seperti di atas mengakibatkan: (1) siswa tidak dapat segera mengetahui hasil tes formatifnya, (2) siswa tidak dapat segera mengetahui jawaban mana yang betul dan yang salah, (3) proses penilaian formatif tidak menarik, (4) siswa terlambat melakukan self remidial terhadap bagian-bagian dari materi pelajaran yang belum dikuasainya, (5) kurang ada tantangan bagi siswa untuk belajar lebih giat, dan (6) tidak merubah perilaku belajar siswa. Mengingat pentingnya peranan evaluasi dalam peningkatan keberhasilan pembelajaran, maka perlu dicari terobosan baru tentang cara pemberian tes kepada siswa yang lebih menarik, lebih cepat diketahui hasilnya, dapat menimbulkan tantangan untuk lebih giat belajar, dan dapat merubah perilaku belajar anak menjadi lebih rajin. Terobosan baru dalam pemberian tes yang sangat mungkin dilakukan adalah tes formatif tertulis berbasis website. Caranya adalah bahwa guru mata pelajaran menyusun soal-soal tes formatif yang dituangkan dalam aplikasi moodle yang digerakkan oleh xamp player atau program lain yang sesuai. Kemudian, aplikasi dimaksud di tampilkan pada website milik sekolah, sehingga siswa dapat mengakses kapan saja dan dimana saja. Soal-soal tes formatif yang dituangkan dalam program moodle di dalamnya sudah tersedia sistem penskoran, sistem umpan balik, sistem waktu, tampilan skor, jenis soal dan berbagai tampilan lain yang dapat di-setting atau di-edit sesuai dengan kebutuhan. Keunggulan mengerjakan tes formatif berbasis website ini adalah: (1) siswa dapat mengakses kapan saja dan dimana saja, (2) soal tes, kunci jawaban, dan sistem penskoran sudah tersedia di dalam web, (3) siswa yang mengerjakan tes melalui web, langsung dapat mengetahui jawaban mana yang betul dan jawaban yang salah secara otomatis, (4) siswa dapat langsung mengetahui skor yang diperolehnya, (5) siswa dapat berkomunikasi langsung dengan guru mata pelajaran melalui web, dan (6) pada akhirnya, menjadikan siswa lebih tertantang 
untuk belajar lebih giat. Selain proses evaluasi yang benar, cepat dan efisien, faktor pengetahuan awal siswa juga memegang peranan dalam menunjang keberhasilan belajar siswa. Pengetahuan awal sebagai kemampuan yang telah dimiliki oleh siswa dari pembelajaran sebelumnya yang akan mempengaruhi pembelajaran selanjutnya. Dengan kata lain, tanpa adanya pengetahuan awal maka siswa akan mengalami kesulitan untuk menerima materi pelajaran berikutnya. Kujawa dan Huske, menjelaskan pengetahuan awal sebagai kombinasi sikap-sikap, pengalaman-pengalaman, dan pengetahuan. Sikap-sikap meliputi (1) kepercayaan diri sebagai siswa, (2) kesadaran tentang minat dan kemampuannya, dan (3) motivasi dan keinginannya untuk membaca. Pengalaman-pengalaman meliupti (1) aktivitas-aktivitas yang berhubungan dengan bacaan, (2) kejadian-kejadian yang memberikan pemahaman, dan (3) pengalaman di dalam keluarga dan masyarakat. Pengetahuan meliputi (1) proses-proses membaca, (2) isi bacaan, (3) topik-topik, (4) konsep-konsep, (5) bentuk dan gaya bacaan, (6) struktur teks, dan (7) akademik dan tujuan personal. (Kujawa, et al, 2010). Pengetahuan awal dapat diketahui dengan melakukan observasi ataupun dengan memberikan tes tertulis, yang menjadi bagian dari evaluasi input (evaluasi masukan). Dengan mengetahui pengetahuan awal siswa, seorang guru akan lebih siap menghadapi kelasnya dan memiliki pilihan-pilihan solusi ketika ada maslah yang terjadi di kelas. Pengetahuan awal merupakan pengetahuan yang telah dimiliki oleh siswa yang didapatkan pada pembelajaran sebelumnya dan akan mempengaruhi hasil pembelajaran selanjutnya. Pengetahuan awal dapat berupa potensi dan kondisi siswa yang telah dimilikinya, pengetahuan yang didapatkan pada pembelajaran sebelumnya, dan pengetahuan prasyarat yang harus dimiliki oleh siswa untuk mengikuti pembelajaran selanjutnya.

\section{METODE PENELITIAN}

Penelitian ini berupa quasi eksperimen yang bertujuan untuk mengetahui pengaruh dari variabel-variabel bebas, yaitu pemberian tes formatif tertulis berbasis website dan pemberian tes formatif secara tertulis berbasis paper and pencil, serta tingkat pengetahuan awal siswa tentang fisika (tinggi dan rendah) terhadap variabel terikat yaitu hasil belajar fisika. Di samping itu, ingin juga diketahui ada tidaknya pengaruh interaksi antara kedua variabel bebas tersebut dalam mempengaruhi hasil belajar fisika. Penelitian ini di laksanakan di MTs Negeri Batam pada Desember 2010 sampai dengan Juni 2011. Populasi penelitian ini seluruh siswa kelas VIII MTsN Batam sebanyak 10 rombongan belajar. Sementara sampel dipilih secara multi stage random sampling dan terpilih kelas VIIIb sebanyak 37 siswa, serta VIIIc sebanyak 37 siswa. Sementara instrumen penelitian dilakukan uji validitas, reliabilitas, tingkat kesukaran, daya daya pembeda.

\section{HASIL DAN PEMBAHASAN}

\section{A. Hasil}

Deskripsi data hasil belajar fisika 8 (delapan) kelompok siswa dapat disajikan pada tabel berikut ini.

Tebel 1. Deskripsi Data Hasil Belajar Fisika Siswa

\begin{tabular}{|c|l|c|c|c|c|c|c|r|}
\hline Data & $\mathrm{n}$ & $\begin{array}{c}\text { Skor } \\
\text { Min }\end{array}$ & $\begin{array}{c}\text { Skor } \\
\text { Maks }\end{array}$ & $\begin{array}{c}\text { Mean } \\
(\overline{\mathrm{X}})\end{array}$ & $\begin{array}{c}\text { Median } \\
(\mathrm{Me})\end{array}$ & $\begin{array}{c}\text { Modus } \\
(\mathrm{Mo})\end{array}$ & $\begin{array}{c}\text { St. Dev } \\
(\mathrm{s})\end{array}$ & $\begin{array}{c}\text { Varians } \\
\left(\mathrm{s}^{2}\right)\end{array}$ \\
\hline $\mathrm{A}_{1}$ & 40 & 12 & 29 & 22,53 & 23,23 & 24,17 & 4,40 & 19,37 \\
\hline $\mathrm{A}_{2}$ & 40 & 12 & 28 & 20,8 & 21,23 & 21,77 & 3,54 & 12,52 \\
\hline $\mathrm{B}_{1}$ & 40 & 12 & 29 & 22,6 & 22,86 & 22,81 & 4,07 & 16,55 \\
\hline $\mathrm{B}_{2}$ & 40 & 12 & 28 & 20,73 & 21,25 & 21,83 & 3,81 & 14,51 \\
\hline $\mathrm{A}_{1} \mathrm{~B}_{1}$ & 20 & 16 & 29 & 24,95 & 25,59 & 26,00 & 3,12 & 9,71 \\
\hline $\mathrm{A}_{2} \mathrm{~B}_{1}$ & 20 & 12 & 26 & 20,05 & 20,88 & 21,83 & 3,29 & 10,83 \\
\hline $\mathrm{A}_{1} \mathrm{~B}_{2}$ & 20 & 12 & 26 & 20,2 & 21,05 & 21,74 & 3,76 & 14,13 \\
\hline $\mathrm{A}_{2} \mathrm{~B}_{2}$ & 20 & 14 & 28 & 21,3 & 21,38 & 21,38 & 3,72 & 13,84 \\
\hline
\end{tabular}


Keterangan:

$A_{1} \quad$ : Skor hasil belajar fisika kelompok siswa yang diberikan tes formatif tertulis berbasis website.

$\mathrm{A}_{2} \quad$ : Skor hasil belajar fisika kelompok siswa yang diberikan tes formatif tertulis berbasis paper and pencil.

$\mathrm{B}_{1} \quad$ : Skor hasil belajar fisika kelompok siswa yang memiliki tingkat pengetahuan awal fisika tinggi.

$\mathrm{B}_{2} \quad$ : Skor hasil belajar fisika kelompok siswa yang memiliki tingkat pengetahuan awal fisika rendah.

$\mathrm{A}_{1} \mathrm{~B}_{1}$ : Skor hasil belajar fisika kelompok siswa yang diberikan tes formatif tertulis berbasis website dan memiliki tingkat pengetahuan awal fisika tinggi.

$\mathrm{A}_{2} \mathrm{~B}_{1} \quad$ : Skor hasil belajar fisika kelompok siswa yang diberikan tes formatif tertulis berbasis paper and pencil dan memiliki tingkat pengetahuan awal fisika tinggi.

$\mathrm{A}_{1} \mathrm{~B}_{2}$ : Skor hasil belajar fisika kelompok siswa yang diberikan tes formatif tertulis berbasis website dan memiliki tingkat pengetahuan awal fisika rendah.

$\mathrm{A}_{2} \mathrm{~B}_{2}$ : Skor hasil belajar fisika kelompok siswa yang diberikan tes formatif tertulis berbasis paper and pencil dan memiliki tingkat pengetahuan awal fisika rendah.

Deskripsi data skor hasil belajar dapat disajikan sebagai berikut:

\section{Data Hasil Belajar Fisika Kelompok Siswa yang Diberikan Tes Formatif Tertulis Berbasis Website $\left(\mathrm{A}_{1}\right)$}

Skor hasil belajar kelompok siswa yang diberikan tes formatif tertulis berbasis Website (A1) terdapat 10 orang siswa atau $25 \%$ memperoleh skor di bawah pada kelas interval yang memuat skor rata-rata, 11 orang atau $27,5 \%$ berada pada kelas interval yang memuat skor ratarata dan 19 orang atau 47,5\% memperoleh skor di atas dari kelas interval yang memuat skor rata-rata. Jika data tersebut dibagi menjadi tiga kategori, maka: (1) Terdapat 10 orang siswa atau $25 \%$ berada pada kategori yang memperoleh skor rendah; (2) Terdapat 11 orang siswa atau 27,5\% memperoleh skor dengan kategori sedang; dan (3) Terdapat 19 orang atau 47,5\% memperoleh skor dengan kategori tinggi. Kemudian apabila kita hitung, kita dapatkan nilai modus (mo) 24,17 dan median (me) 23,23 lebih besar dari harga rata-rata $(\bar{X})$ 22,53 maka berdasarkan hasil penilaian acuan norma skor yang diperoleh siswa yang diberikan tes formatif tertulis berbasis website cenderung tinggi dari skor rata-rata yang diperoleh dari cara pemberian tes formatif tersebut

\section{Data Hasil Belajar Fisika Kelompok Siswa yang Diberikan Tes Formatif Tertulis Berbasis Paper and Pencil (A $\left.\mathbf{A}_{2}\right)$}

Data hasil belajar fisika kelompok siswa yang diberikan tes formatif tertulis berbasis paper and pencil (A2) terdapat 7 orang siswa atau 17,50\% memperoleh skor di bawah kelas interval yang memuat skor rata-rata, 27 orang atau $67,5 \%$ berada pada kelas interval yang memuat skor rata-rata dan 6 orang atau $15 \%$ memperoleh skor di atas kelas interval yang memuat skor rata-rata. Apabila dikelompokkan, maka terdapat 7 orang atau 17,5\% berada pada kategori yang memperoleh skor rendah, 27 orang atau 67,5\% berada pada kategori yang memperoleh skor sedang dan 6 orang atau $15 \%$ memperoleh skor dengan kategori tinggi. Selanjutnya jika dianalisis secara statistik, maka didapatkan harga modus (mo) 21,77 median (me) 21,23 lebih besar dari skor rata-rata $(\bar{X})$ 20,8. Berdasarkan penilaian acuan norma skor hasil belajar siswa yang diberikan tes formatif tertulis berbasis paper and pencil cenderung tinggi dari skor rata-rata yang diperoleh dari cara pemberian tes formatif.

\section{Data Hasil Belajar Fisika Kelompok Siswa yang Memiliki Tingkat Pengetahuan Awal Fisika Tinggi $\left(\mathrm{B}_{1}\right)$}

Data hasil belajar fisika kelompok siswa yang memiliki tingkat pengetahuan awal 
fisika tinggi (B1) didapatkan 9 orang siswa atau 22,5\% memperoleh skor di bawah kelas interval yang memuat skor rata-rata, 14 orang atau $35 \%$ berada pada kelas interval yang memuat skor rata-rata dan 17 orang atau 42,5\% memperoleh skor di atas kelas interval yang memuat skor rata-rata. Jika dikelompokkan menjadi tiga kelompok, maka terdapat 9 orang siswa atau $22,5 \%$ berada pada kategori yang memperoleh skor rendah, 14 orang siswa atau 35\% memperoleh skor dengan kategori sedang dan 17 orang siswa atau 42,5\% memperoleh skor dengan kategori tinggi. Selanjutnya, jika dilihat harga modus (mo) 22,81 dan median (me) 22,86 lebih besar dari skor rata-rata $(\bar{X}) 22,6$. Maka berdasarkan penilaian acuan norma skor hasil belajar fisika siswa yang diperoleh oleh kelompok siswa yang mempunyai tingkat pengetahuan awal tinggi cenderung tinggi dari skor rata-rata.

\section{Data Hasil Belajar Fisika Kelompok Siswa yang Memiliki Tingkat Pengetahuan Awal Fisika Rendah $\left(\mathbf{B}_{2}\right)$}

Data hasil belajar fisika kelompok siswa yang memiliki tingkat pengetahuan awal fisika rendah (B2) didapatkanc8 orang siswa atau 20\% memperoleh skor di bawah kelas interval yang memuat skor rata-rata, 24 orang atau $60 \%$ berada pada kelas interval yang memuat skor rata-rata dan 8 orang atau $20 \%$ memperoleh skor di atas kelas interval yang memuat skor ratarata. Jika dikelompokkan menjadi tiga kelompok, maka terdapat 8 orang siswa atau $20 \%$ berada pada kategori yang memperoleh skor rendah, 24 orang siswa atau $60 \%$ memperoleh skor dengan kategori sedang dan 8 orang siswa atau 20\% memperoleh skor dengan kategori tinggi. Selanjutnya, jika dilihat harga modus (mo) 21,83 dan median (me) 21,25 lebih besar dari skor rata-rata $\left(X^{\top}\right)$ 20,73. Berdasarkan penilaian acuan norma skor hasil belajar fisika siswa yang diperoleh oleh kelompok siswa yang mempunyai tingkat pengetahuan awal rendah cenderung tinggi dari skor rata-rata.

\section{Data Hasil Belajar Fisika Kelompok Siswa yang Diberikan Tes Foramtif Tertulis Berbasis Website dan Memiliki Tingkat Pengetahuan Awal Fisika Tinggi $\left(\mathrm{A}_{1} \mathrm{~B}_{1}\right)$}

Dalam kelompok ini, skor hasil belajar fisika tertinggi adalah 29 dan skor terendah 16. Berdasarkan hasil perhitungan diperoleh skor rata-rata $(\bar{X})$ sebesar 24,95 dengan simpangan baku $(s)$ 3,12. Hasil perhitungan selanjutnya diperoleh harga modus (mo) sebesar 26,00 dan median (me) sebesar 25,59. Hasil penghitungan selanjutnya terdapat 3 orang siswa atau $15 \%$ memperoleh skor di bawah kelas interval yang memuat skor rata-rata, 14 orang atau $70 \%$ berada pada kelas interval yang memuat skor rata-rata dan 3 orang atau $15 \%$ memperoleh skor di atas kelas interval yang memuat skor rata-rata. Apabila dikelompokkan, maka terdapat 3 orang siswa atau $15 \%$ berada pada kategori yang memperoleh skor rendah, 14 orang siswa atau $70 \%$ memperoleh skor dengan kategori sedang dan 3 orang siswa atau 15\% memperoleh skor dengan kategori tinggi. Selanjutnya, jika dilihat harga modus (mo) 26,00 dan median (me) 25,59 lebih besar dari skor rata-rata $(\bar{X}) 24,95$ maka berdasarkan penilaian acuan norma skor hasil belajar fisika siswa yang diperoleh oleh kelompok siswa yang diberikan tes formatif tertulis berbasis website dan mempunyai tingkat pengetahuan awal tinggi cenderung tinggi dari skor rata-rata.

\section{Data Hasil Belajar Fisika Kelompok Siswa yang Diberikan Tes Formatif Tertulis Berbasis Paper and Pencil dan Memiliki Tingkat Pengetahuan Awal Fisika Tinggi $\left(\mathbf{A}_{2} B_{1}\right)$}

Dalam kelompok ini, skor hasil belajar fisika tertinggi adalah 26 dan skor terendah 12. Berdasarkan hasil perhitungan diperoleh skor rata-rata $(\bar{X})$ sebesar 20,05 dan simpangan baku (s) 3,29. Hasil perhitungan selanjutnya diperoleh harga modus (mo) sebesar 21,83 dan median (me) sebesar 20,88. Secara prosentase didapatkan sebanyak 5 orang siswa atau $25 \%$ memperoleh skor di bawah kelas interval yang memuat skor rata-rata, 12 orang atau $60 \%$ berada pada kelas interval yang memuat skor rata-rata dan 3 orang atau 15\% memperoleh skor di atas kelas interval yang memuat skor rata-rata. Jika skor kelima kelas interval di atas dibagi dalam tiga kategori, yaitu skor pada kelas interval 1 dan 2 dikategorikan rendah, kelas interval 3, dan 
4 dikategorikan sedang dan skor pada kelas interval 5 dikategorikan tinggi, maka terdapat 5 orang siswa atau $25 \%$ berada pada kategori yang memperoleh skor rendah, 12 orang siswa atau $60 \%$ memperoleh skor dengan kategori sedang dan 3 orang siswa atau 15\% memperoleh skor dengan kategori tinggi. Selanjutnya, jika dilihat harga modus (mo) 21,83 dan median (me) 20,88 lebih besar dari skor rata-rata $(\bar{x}) 20,05$, maka berdasarkan penilaian acuan norma skor hasil belajar fisika siswa yang diperoleh oleh kelompok siswa yang diberikan tes formatif tertulis berbasis paper and pencil dan mempunyai tingkat pengetahuan awal tinggi cenderung tinggi dari skor rata-rata.

\section{Data Hasil Belajar Fisika Kelompok Siswa yang Diberikan Tes Foramtif Tertulis Berbasis Website dan Memiliki Tingkat Pengetahuan Awal Fisika Rendah $\left(\mathrm{A}_{1} \mathrm{~B}_{2}\right)$}

Jumlah butir tes pada kelompok ini sebanyak 30 butir yang memiliki rentang skor 1 sampai dengan 30, dengan jumlah responden sebanyak 20 orang. Dalam kelompok ini, skor hasil belajar fisika tertinggi adalah 26 dan skor terendah 12. Berdasarkan hasil perhitungan diperoleh skor rata-rata $(\bar{X})$ sebesar 20,2 dengan simpangan baku (s) 3,76. Hasil perhitungan selanjutnya diperoleh harga modus (mo) sebesar 21,74 dan median (me) sebesar 21,02. Secara persentase, terdapat 4 orang siswa atau $20 \%$ memperoleh skor di bawah kelas interval yang memuat skor rata-rata, 15 orang atau $75 \%$ berada pada kelas interval yang memuat skor ratarata dan 1 orang atau 5\% memperoleh skor di atas kelas interval yang memuat skor rata-rata. Jika skor keenam kelas interval di atas dibagi dalam tiga kategori, yaitu skor pada kelas interval 1 dan 2 dikategorikan rendah, kelas interval 3 dan 4 dikategorikan sedang dan skor pada kelas interval 5 dikategorikan tinggi, maka terdapat 4 orang siswa atau 20\% berada pada kategori yang memperoleh skor rendah, 15 orang siswa atau $75 \%$ memperoleh skor dengan kategori sedang dan 1 orang siswa atau 5\% memperoleh skor dengan kategori tinggi. Selanjutnya, jika dilihat harga modus (mo) 21,74 dan median (me) 21,05 lebih tinggi dari skor rata-rata $(\bar{X})$ 20,2 maka berdasarkan penilaian acuan norma skor hasil belajar fisika siswa yang diperoleh oleh kelompok siswa yang diberikan tes formatif tertulis berbasis website dan mempunyai tingkat pengetahuan awal rendah cenderung tinggi dari skor rata-rata.

\section{Data Hasil Belajar Fisika Kelompok Siswa yang Diberikan Tes Formatif Tertulis Berbasis Paper and Pencil dan Memiliki Tingkat Pengetahuan Awal Fisika Rendah $\left(\mathbf{A}_{2} \mathbf{B}_{2}\right)$}

Tes hasil belajar fisika yang berjumlah 30 butir memiliki rentang skor teoritik 1 sampai dengan 30. Skor hasil belajar fisika diperoleh dari kelompok siswa yang diberikan tes formatif tertulis berbasis paper and pencil dan memiliki tingkat pengetahuan awal rendah berjumlah 20 siswa sebagai responden. Dalam kelompok ini, skor hasil belajar fisika tertinggi adalah 28 dan skor terendah 14. Berdasarkan hasil perhitungan diperoleh skor rata-rata $(\bar{X})$ sebesar 21,3 dengan simpangan baku (s) 3,72. Hasil perhitungan selanjutnya diperoleh harga modus (mo) sebesar 21,38 dan median (me) sebesar 21,38. Hasil perhitungan persentasenya terdapat 5 orang siswa atau $25 \%$ memperoleh skor di bawah kelas interval yang memuat skor rata-rata, 8 orang atau $40 \%$ berada pada kelas interval yang memuat skor rata-rata dan 7 orang atau 35\% memperoleh skor di atas kelas interval yang memuat skor rata-rata. Jika skor kelima kelas interval di atas dibagi dalam tiga kategori, yaitu skor pada kelas interval 1 dan 2 dikategorikan rendah, kelas interval 3 dikategorikan sedang dan skor pada kelas interval 4 dan 5 dikategorikan tinggi, maka terdapat 5 orang siswa atau $25 \%$ berada pada kategori yang memperoleh skor rendah, 8 orang siswa atau $40 \%$ memperoleh skor dengan kategori sedang dan 7 orang siswa atau 35\% memperoleh skor dengan kategori tinggi. Selanjutnya, jika dilihat harga modus (mo) 21,38 dan median (me) 21,38 lebih tinggi dari skor rata-rata $(\bar{X})$ 21,3, maka berdasarkan penilaian acuan norma skor hasil belajar fisika siswa yang diperoleh oleh kelompok siswa yang diberikan tes formatif tertulis berbasis paper and pencil dan mempunyai tingkat pengetahuan awal rendah cenderung tinggi dari skor rata-rata. 


\section{B. Pengujian Persyaratan Analisis}

\section{Uji Normalitas Data}

Uji normalitas dilakukan terhadap hasil belajar fisika siswa pada masing-masing kelompok perlakuan. Dengan demikian ada 8 (delapan) kelompok data yang diuji normalitasnya sebagai berikut: (1) Data hasil belajar fisika siswa yang diberikan tes formatif tertulis berbasis website $\left(\mathrm{A}_{1}\right)$; (2) Data hasil belajar fisika siswa yang diberikan tes formatif tertulis berbasis paper and pencil $\left(\mathrm{A}_{2}\right)$; (3) Data hasil belajar fisika siswa yang memiliki tingkat pengetahuan awal tinggi ( $\left.\mathrm{B}_{1}\right)$; (4) Data hasil belajar fisika siswa yang memiliki tingkat pengetahuan awal rendah $\left(\mathrm{B}_{2}\right)$; (5) Data hasil belajar fisika siswa yang diberikan tes formatif tertulis berbasis website dan memiliki tingkat pengetahuan awal tinggi $\left(\mathrm{A}_{1} \mathrm{~B}_{1}\right)$; (6) Data hasil belajar fisika siswa yang diberikan tes formatif tertulis berbasis website dan memiliki tingkat pengetahuan awal rendah $\left(\mathrm{A}_{1} \mathrm{~B}_{2}\right)$; (7) Data hasil belajar fisika siswa yang diberikan tes formatif tertulis berbasis paper and pencil dan memiliki tingkat pengetahuan awal tinggi $\left(\mathrm{A}_{2} \mathrm{~B}_{1}\right)$; dan $(8)$ Data hasil belajar fisika siswa yang diberikan tes formatif tertulis berbasis paper and pencil dan memiliki tingkat pengetahuan awal rendah $\left(\mathrm{A}_{2} \mathrm{~B}_{2}\right)$. Hasil perhitungan dengan uji Lillifors menunjukkan bahwa delapan kelompok data tersebut memiliki tingkat normalitas data seperti tertera pada tabel berikut ini:

Tabel 2. Hasil Uji Normalitas Data Hasil Belajar Fisika Pada Masing-masing Kelompok

\begin{tabular}{|c|c|c|c|c|}
\hline Kelompok & $\mathrm{n}$ & $\mathrm{L}_{\mathrm{o}}$ & $\mathrm{L}_{\mathrm{t}(\alpha=0,01)}$ & Kesimpulan \\
\hline $\mathrm{A}_{1}$ & 40 & 0,0976 & 0,1630 & Normal \\
\hline $\mathrm{A}_{2}$ & 40 & 0,1171 & 0,1630 & Normal \\
\hline $\mathrm{B}_{1}$ & 40 & 0,0661 & 0,1630 & Normal \\
\hline $\mathrm{B}_{2}$ & 40 & 0,0792 & 0,1630 & Normal \\
\hline $\mathrm{A}_{1} \mathrm{~B}_{1}$ & 20 & 0,1264 & 0,2305 & Normal \\
\hline $\mathrm{A}_{2} \mathrm{~B}_{1}$ & 20 & 0,1391 & 0,2305 & Normal \\
\hline $\mathrm{A}_{1} \mathrm{~B}_{2}$ & 20 & 0,0883 & 0,2305 & Normal \\
\hline $\mathrm{A}_{2} \mathrm{~B}_{2}$ & 20 & 0,0819 & 0,2305 & Normal \\
\hline
\end{tabular}

Pada tabel di atas dapat dilihat bahwa Lo dari kedelapan kelompok tersebut lebih kecil dari $\mathrm{L}_{\mathrm{t}}\left(\mathrm{L}_{\mathrm{o}}<\mathrm{L}_{\mathrm{t}}\right)$, ini berarti $\mathrm{H}_{\mathrm{o}}$ diterima. Dengan demikian dapat disimpulkan bahwa sampel dari 8 (delapan) kelompok di atas adalah berasal dari populasi yang berdistribusi normal.

\section{Uji Homogenitas Data}

Dalam penelitian ini uji homogenitas data dilakukan terhadap: (a) dua kelompok perlakuan, yaitu antara kelompok siswa yang diberikan tes formatif tertulis berbasis website $\left(A_{1}\right)$ dan kelompok siswa yang diberikan tes formatif tertulis berbasis paper and pencil $\left(A_{2}\right),(b)$ dua kelompok kategori atribut subjek penelitian, yaitu antara kelompok siswa yang mempunyai tingkat pengetahuan awal tinggi $\left(B_{1}\right)$ dan kelompok siswa yang mempunyai tingkat pengetahuan awal rendah $\left(\mathrm{B}_{2}\right)$, (c) empat kelompok sel dalam rancangan eksperimen, yaitu antara kelompok siswa yang diberikan tes formatif tertulis berbasis website dan mempunyai tingkat pengetahuan awal tinggi $\left(\mathrm{A}_{1} \mathrm{~B}_{1}\right)$, kelompok siswa yang diberikan tes formatif tertulis berbasis website dan mempunyai tingkat pengetahuan awal rendah $\left(\mathrm{A}_{1} \mathrm{~B}_{2}\right)$, kelompok siswa yang diberikan tes formatif tertulis berbasis paper and pencil dan mempunyai tingkat pengetahuan awal tinggi $\left(\mathrm{A}_{2} \mathrm{~B}_{1}\right)$, dan kelompok siswa yang diberikan tes formatif tertulis berbasis paper and pencil dan memiliki tingkat pengetahuan awal rendah $\left(\mathrm{A}_{2} \mathrm{~B}_{2}\right)$. Hasil penghitungan uji homogenitas varians diperoleh $\mathrm{F}_{\text {hitung }}=1,5471<\mathrm{F}_{(0,01)(39,39)}=2,1352$ atau $F_{\text {hitung }}=1,5471<\mathrm{F}_{(0,05)(39,39)}=1,7045$. Jika dibandingkan $F_{\text {hitung }}$ lebih kecil dari $F_{\text {tabel }}$, dengan demikian $\mathrm{H}_{\mathrm{o}}$ diterima. Hal ini berarti tidak ada perbedaan varians antara dua kelompok perlakuan yang diuji, yaitu kelompok siswa yang diberikan tes formatif tertulis berbasis website $\left(\mathrm{A}_{1}\right)$ dan kelompok siswa yang diberikan tes formatif secara tertulis berbasis paper and pencil $\left(\mathrm{A}_{2}\right)$. Artinya bahwa kedua kelompok data tersebut berasal dari populasi yang homogen. 


\subsection{Uji Homogenitas Varians pada Dua Kelompok Kategori Atribut Subjek Penelitian (B1 dan $B_{2}$ )}

Pengujian homogenitas dari kelompok-kelompok kategori atribut dalam penelitian ini dilakukan seperti langkah pada point (a). Kelompok-kelompok tersebut adalah kelompok siswa yang mempunyai tingkat pengetahuan tinggi $\left(\mathrm{B}_{1}\right)$ dan kelompok siswa yang mempunyai tingkat pengetahuan awal rendah $\left(\mathrm{B}_{2}\right)$. Hasil penghitungan uji homogenitas varians diperoleh $\mathrm{F}_{\text {hitung }}=$ $1,1407<\mathrm{F}_{(0,01)(39,39)}=2,1352$ atau $\mathrm{F}_{\text {hitung }}=1,1407<\mathrm{F}_{(0,05)(39,39)}=1,7045$. Jika dibandingkan $\mathrm{F}_{\text {hitung }}$ lebih kecil dari $\mathrm{F}_{\text {tabel}}$, dengan demikian $\mathrm{H}_{\mathrm{o}}$ diterima. Hal ini berarti tidak ada perbedaan varians antara dua kelompok perlakuan yang diuji, yaitu kelompok siswa yang memiliki tingkat pengetahuan awal tinggi $\left(\mathrm{B}_{1}\right)$ dan kelompok siswa yang memiliki tingkat pengetahuan awal rendah $\left(\mathrm{B}_{2}\right)$. Berdasarkan analisis di atas dapat disimpulkan bahwa data kedua kelompok tersebut berasal dari populasi yang berdistribusi homogen.

\subsection{Uji Homogenitas Varians pada Dua Kelompok Kategori Atribut Subjek Penelitian (B1 dan $B_{2}$ )}

Pengujian homogenitas dari kelompok-kelompok kategori atribut dalam penelitian ini dilakukan seperti langkah pada point (a). Kelompok-kelompok tersebut adalah kelompok siswa yang mempunyai tingkat pengetahuan tinggi $\left(B_{1}\right)$ dan kelompok siswa yang mempunyai tingkat pengetahuan awal rendah $\left(\mathrm{B}_{2}\right)$. Hasil penghitungan uji homogenitas varians diperoleh $\mathrm{F}_{\text {hitung }}=$ $1,1407<\mathrm{F}(0,01)(39,39)=2,1352$ atau $F_{\text {hitung }}=1,1407<\mathrm{F}(0,05)(39,39)=1,7045$. Jika dibandingkan $\mathrm{F}_{\text {hitung }}$ lebih kecil dari $\mathrm{F}_{\text {tabel }}$, dengan demikian $\mathrm{H}_{\mathrm{o}}$ diterima. Hal ini berarti tidak ada perbedaan varians antara dua kelompok perlakuan yang diuji, yaitu kelompok siswa yang memiliki tingkat pengetahuan awal tinggi $\left(\mathrm{B}_{1}\right)$ dan kelompok siswa yang memiliki tingkat pengetahuan awal rendah $\left(\mathrm{B}_{2}\right)$. Berdasarkan anailisis di atas dapat disimpulkan bahwa data kedua kelompok tersebut berasal dari populasi yang berdistribusi homogen.

\subsection{Uji Homogenitas Varians pada Empat Kelompok Sel Dalam Rancangan Eksperimen (Antara $A_{1} B_{1}, A_{1} B_{2}, A_{2} B_{1}, A_{2} B_{2}$ )}

Pengujian homogenitas varians empat kelompok dalam penelitian ini, yaitu: (1) kelompok siswa yang diberikan tes formatif tertulis berbasis website dan memiliki tingkat pengetahuan awal tinggi $\left(\mathrm{A}_{1} \mathrm{~B}_{1}\right)$, (2) kelompok siswa yang diberikan tes formatif tertulis berbasis website dan memiliki tingkat pengetahuan awal rendah $\left(\mathrm{A}_{1} \mathrm{~B}_{2}\right)$, (3) kelompok siswa yang diberikan tes formatif tertulis berbasis paper and pencil dan memiliki tingkat pengetahuan awal tinggi $\left(\mathrm{A}_{2} \mathrm{~B}_{1}\right)$, dan (4) kelompok siswa yang diberikan tes formatif tertulis berbasis paper and pencil dan memiliki tingkat pengetahuan awal rendah $\left(\mathrm{A}_{2} \mathrm{~B}_{2}\right)$ dilakukan dengan menggunakan uji Bartlett. Hasil uji Bartlett didapatkan $\chi^{2}$ hit $=0,958<\chi_{(1-\alpha)(\mathrm{k}-1)}^{2}=11,34$ pada taraf nyata 0,01 atau $\chi^{2}$ hit $=0,958<\chi^{2}(1-\alpha)(\mathrm{k}-1)=7,82$ pada taraf nyata 0,05 , dengan demikian $\mathrm{H}_{\mathrm{o}}$ diterima. Hal ini berarti tidak ada perbedaan varians antara keempat kelompok yang diuji, dan kesimpulannya bahwa data keempat kelompok tersebut berasal dari populasi yang homogen.

\section{Pengujian Hipotesis Penelitian}

Pengujian hipotesis penelitian ini dilakukan dengan teknik analisis varians dua jalur (ANAVA 2 X 2), kemudian dilakukan uji lanjut dengan uji Tukey. Ringkasan perhitungan ANAVA 2 jalur sebagaimana tertera pada tabel berikut ini:

Tabel 3. Ringkasan Hasil Perhitungan ANAVA Dua Jalan Data Hasil Belajar Fisika

\begin{tabular}{|c|c|c|r|r|r|r|}
\hline $\begin{array}{c}\text { Sumber } \\
\text { Varians }\end{array}$ & $\begin{array}{c}\text { Jumlah } \\
\text { Kuadrat } \\
(\mathrm{JK})\end{array}$ & $\mathrm{db}$ & $\begin{array}{c}\text { Rata-rata Jlh } \\
\text { Kuadrat } \\
(\mathrm{RJK})\end{array}$ & $\mathrm{F}_{\text {hitung }}$ & & \multicolumn{2}{|c|}{$\mathrm{F}_{\text {tabel }}$} \\
\cline { 5 - 8 } & 51,2 & 1 & 51,2 & $4,221^{*}$ & 3,967 & 6,981 \\
\hline
\end{tabular}


TEACHING : Jurnal Inovasi Keguruan dan Ilmu Pendidikan

Vol. 1. No. 4 Desember 2021 e-ISSN : 2775-7188 | p-ISSN : 2775-717X

\begin{tabular}{|l|r|r|r|r|r|c|}
\hline Antar Baris (B) & 84,05 & 1 & 84,05 & $6,929 *$ & 3,967 & 6,981 \\
\hline Interaksi A x B & 238,05 & 1 & 238,05 & $19,625 * *$ & 3,967 & 6,981 \\
\hline $\begin{array}{l}\text { Kekeliruan Dalam Kelompok } \\
\text { (D) }\end{array}$ & 921,9 & 76 & 12,13 & - & - & - \\
\hline Total Direduksi & 1295,2 & 79 & 385,43 & - & - & - \\
\hline
\end{tabular}

Keterangan:

$$
* \text { = signifikan } * *=\text { sangat signifikan } \quad \mathrm{db}=\text { derajat kebebasan }
$$

Berdasakan ringkasan perhitungan ANAVA di atas, dapat dijelaskan:

1. Hasil analisis varians dua jalur antar kolom diperoleh harga $F_{\text {hitung }}=4,221>F_{\text {tabel }}=3,967$ pada taraf signifikansi $\alpha=0,05$. Hal ini berarti bahwa hipotesis nol yang menyatakan tidak terdapat perbedaan hasil belajar fisika antara siswa yang diberikan tes formatif tertulis berbasis website dengan siswa yang diberikan tes formatif tertulis berbasis paper and pencil ditolak. Dengan demikian hipotesis alternatif yang menyatakan terdapat perbedaan hasil belajar fisika antara siswa yang diberikan tes formatif tertulis berbasis website dengan siswa yang diberikan tes formatif tertulis berbasis paper and pencil diterima. Melihat adanya perbedaan hasil belajar fisika ini, maka dapa dilihat mana yang lebih tinggi hasil belajar fisika antara dua perlakuan. Hasil perhitungan menunjukkan skor rata-rata $(\overline{\mathrm{X}})$ hasil belajar fisika siswa yang diberikan tes formatif tertulis berbasis website $\left(\mathrm{A}_{1}\right)$ lebih tinggi dari skor rata-rata $(\overline{\mathrm{X}})$ hasil belajar fisika siswa yang diberikan tes formatif tertulis berbasis paper and pencil $\left(\mathrm{A}_{2}\right)$. Dengan demikian hipotesis pertama yang menyatakan secara keseluruhan hasil belajar fisika siswa yang diberikan tes formatif tertulis berbasis website lebih tinggi dari hasil belajar fisika siswa yang diberikan tes formatif tertulis berbasis paper and pencil diterima secara signifikan.

2. Hasil analisis varian dua jalur antar baris diperoleh harga $F_{\text {hitung }}=6,929$ lebih besar dari $\mathrm{F}_{\text {tabel }}=3,967$ pada taraf signifikansi 0,05 . Hal ini berarti hipotesis nol yang menyatakan bahwa tidak terdapat perbedaan hasil belajar fisika kelompok siswa yang memiliki tingkat pengetahuan awal tinggi dan tingkat pengetahuan awal rendah ditolak. Ini berarti bahwa hipotesis alternatif yang menyatakan terdapat perbedaan hasil belajar fisika antara kelompok siswa yang memiliki tingkat pengetahuan awal tinggi dan tingkat pengetahuan awal rendah diterima secara signifikan. Dengan adanya perbedaan hasil belajar fisika antara kedua kelompok itu, maka dapat dilihat perbedaan rata-rata hasil belajar antara kedua kelompok atribut itu. Hasil perhitungan menunjukkan skor rata-rata hasil belajar fisika kelompok siswa yang memiliki tingkat pengetahuan awal tinggi $\left(\mathrm{B}_{1}\right)$ lebih tinggi dari skor rata-rata hasil belajar kelompok siswa yang memiliki tingkat pengetahuan awal rendah $\left(\mathrm{B}_{2}\right)$. Dengan demikian hipotesis kedua yang menyatakan, secara keseluruhan hasil belajar fisika siswa yang memiliki tingkat pengetahuan awal tinggi $\left(\mathrm{B}_{1}\right)$ lebih tinggi dari hasil belajar fisika siswa yang memiliki tingkat pengetahuan awal rendah $\left(\mathrm{B}_{2}\right)$.

3. Hasil analisis dua varians dua jalur interaksi antar kolom dan baris diperoleh harga $F_{\text {hitung }}=$ 19,625 lebih besar dari $\mathrm{F}_{\text {tabel }}=3,967$ pada taraf signifikansi $\alpha=0,05$. Hal ini berarti bahwa hipotesis nol yang menyatakan tidak terdapat interaksi antara pemberian tes formatif dengan tingkat pengetahuan awal siswa terhadap hasil belajar fisika ditolak. Dengan demikian hipotesis alternatif yang menyatakan terdapat pengaruh interaksi antara pemberian tes formatif dengan tingkat pengetahuan awal siswa terhadap hasil belajar fisika diterima secara signifikan. Bentuk interaksi antara keduanya dapat dilihat pada gambar berikut ini: (1) Jika kelompok siswa yang memiliki tigkat pengetahuan awal tinggi diberikan tes formatif tertulis berbasis website, maka hasil belajar fisikanya akan tinggi; (2) Jika kelompok siswa yang memiliki tingkat pengetahuan awal rendah diberikan tes formatif tertulis berbasis paper and pencil, maka hasil belajar fisikanya akan tinggi; (3) Jika kelompok siswa yang berpengetahuan awal tinggi diberikan tes formatif tertulis berbasis paper and pencil maka 
hasil belajar fisikanya akan rendah, dan (4) Jika kelompok siswa yang memiliki tingkat pengetahuan awal rendah diberikan tes formatif berbasis website maka hasil belajar fisikanya akan rendah. Hasil perhitungan besar pengaruh interaksi antara variabel bebas (tes formatif tertulis dan tingkat pengetahuan awal) terhadap variabel terikat (hasil belajar fisika siswa) diperoleh skor 0,1888. Dengan demikian, pengaruh interaksi pemberian tes formatif tertulis dan tingkat pengetahuan awal dapat menjelaskan $18,88 \%$ variansi hasil belajar fisika siswa. Artinya, bahwa pemberian tes formatif tertulis dan tingkat pengetahuan awal dapat memberikan sumbangan sebesar 18,88\% terhadap kenaikan hasil belajar fisika siswa. Dengan adanya pengaruh interaksi antara pemberian tes formatif tertulis dan tingkat pengetahuan awal, maka dilakukan uji lanjutan yang dimaksudkan untuk mengetahui perbedaan setiap pasang kelompok, karena banyaknya sampel pada setiap kelompok jumlahnya sama, maka digunakan uji Tukey. Keempat kelompok, baik secara vertikal maupun horisontal layak dibandingkan. Berdasarkan hasil pengujian ANAVA dua jalan terdapat adanya interaksi yang signifikan antara pemberian tes formatif dan tingkat pengetahuan awal siswa terhadap hasil belajar fisika, maka untuk membuktikan tentang adanya perbedaan pengaruh dari interaksi kedua variabel tersebut terhadap hasil belajar fisika harus dilakukan pengujian pengaruh sederhana atau simple effect-nya. Sebelum perbedaan rerata antara kelompok perlakuan dilakukan uji perbedaan/persamaan dari empat kelompok perlakuan dengan penerapan prosedur varians satu jalan. $F_{\text {hitung }}=10,26>F_{\text {tabel }}$ $=2,725$ pada taraf signifikansi 0,05 . Berarti hipotesis nol yang menyatakan bahwa tidak terdapat perbedaan rata-rata hasil belajar antara empat kelompok/sel adalah ditolak. Dengan demikian hipotesis alternatif yang menyatakan ada perbedaan rata-rata skor hasil belajar fisika antara empat kelompok/sel diterima. Untuk menentukan kebermaknaan pengaruh interaksi diantara variabel penelitian, maka dalam penelitian ini dilakukan uji lanjutan dengan uji Tukey, mengingat jumlah subjek/sampel (n) pada setiap kelompok/sel adalah sama. Analisis ini digunakan untuk menguji perbedaan skor antara skor absolut dari dua kelompok yang dipasangkan dengan membandingkan dengan nilai kritis (nilai tabel). Dalam penelitian ini dilakukan terhadap 2 (dua) kelompok subjek sebagai berikut: (a) Kelompok siswa yang diberikan tes formatif tertulis berbasis website dan memiliki tingkat pengetahuan awal tinggi serta kelompok siswa yang diberikan tes formatif tertulis berbasis paper and pencil dan memiliki tingkat pengetahuan awal tinggi $\left(\mathrm{A}_{1} \mathrm{~B}_{1}\right.$ dan $\left.\mathrm{A}_{2} \mathrm{~B}_{1}\right)$; dan (b) Kelompok siswa yang diberikan tes formatif tertulis berbasis paper and pencil dan memiliki tingkat pengetahuan awal rendah serta kelompok siswa yang diberikan tes formatif tertulis berbasis website dan memiliki tingkat pengetahuan awal rendah $\left(\mathrm{A}_{2} \mathrm{~B}_{2}\right.$ dan $\left.\mathrm{A}_{1} \mathrm{~B}_{2}\right)$. Hasil penghitungan uji lanjut dengan uji Tukey untuk kedua kelompok yang dibandingkan, dapat disimpulkan sebagai berikut: (1) Hasil analisis dengan uji Tukey untuk kelompok siswa $\left(\mathrm{A}_{1} \mathrm{~B}_{1}\right)$ yang memiliki tingkat pengetahuan awal tinggi menunjukkan, bahwa tes formatif berbasis website memberikan pengaruh yang lebih baik terhadap hasil belajar fisika tes formatif tertulis berbasis paper and pencil $\left(\mathrm{A}_{2} \mathrm{~B}_{1}\right)$. Hal ini terbukti bahwa harga $\mathrm{Q}_{\text {hitung }}=$ $6,29>Q_{\text {tabel }} 2,95(\alpha=0,05)$. Juga nilai rata-rata hasil belajar kelompok $\mathrm{A}_{1} \mathrm{~B}_{1}(\overline{\mathrm{X}}=24,95)$ lebih tinggi dari kelompok $\mathrm{A}_{2} \mathrm{~B}_{1}(\overline{\mathrm{X}}=20,05)$. Artinya hipotesis ini diterima atau teruji secara signifikan; (2) Hasil analisis dari uji Tukey untuk kelompok siswa $\left(\mathrm{A}_{2} \mathrm{~B}_{2}\right)$ yang memiliki tingkat pengetahuan awal rendah menunjukkan, bahwa tes formatif tertulis berbasis paper and pencil memberikan pengaruh yang lebih baik terhadap hasil belajar fisika dibandingkan dengan tes formatif tertulis berbasis website $\left(\mathrm{A}_{1} \mathrm{~B}_{2}\right)$. Harga $\mathrm{Q}_{\text {hitung }}=1,41<\mathrm{Q}_{\text {tabel }} 2,95(\alpha=$ $0,05)$, dan nilai rata-rata hasil belajar kelompok $\mathrm{A}_{2} \mathrm{~B}_{2}(\overline{\mathrm{X}}=21,3)$ lebih tinggi dari kelompok $\mathrm{A}_{1} \mathrm{~B}_{2}(\bar{X}=20,2)$. Artinya hipotesis ini diterima atau teruji secara tidak signifikan.

\section{Pembahasan Hasil Penelitian}

Pada dasarnya tujuan penelitian ini adalah untuk memperoleh suatu perbedaan hasil belajar kelompok siswa yang diberikan tes formatif tertulis berbasis website dengan kelompok siswa yang diberikan tes formatif tertulis berbasis paper and pencil, dengan tujuan untuk 
memperoleh suatu pembaharuan atau inovasi yang lebih baik dalam proses penilaian hasil belajar fisika di Madrasah Tsanawiyah (MTs) dan/atau Sekolah Menengah Pertama (SMP). Rata-rata hasil skor penilaian kelompok Paper Based Test (PBT) lebih rendah dari hasil skor penilaian kelompok Computer Based Test (CBT), maka peserta tes pada sekolah tersebut dinyatakan telah siap menghadapi ujian berbasis komputer. Namun, jika didapatkan besarnya rata-rata hasil skor penilaian kelompok PBT lebih tinggi dari hasil skor penilaian kelompok CBT, maka peserta tes pada sekolah tersebut dinyatakan belum siap menghadapi ujian berbasis computer (Patta, 2020). Selanjutnya, berdasarkan temuan hasil penelitian di atas, maka dapat dilakukan pembahasan sebagai berikut:

1. Hasil Belajar Fisika Kelompok Siswa yang Diberikan Tes Formatif Tertulis Berbasis Website Lebih Tinggi Dibandingkan Dengan Hasil Belajar Fisika Kelompok Siswa yang Diberikan Tes Tormatif Secara Tertulis Berbasis Paper and Pencil.

Kenyataan empiris tersebut dapat dijelaskan bahwa pemberian tes formatif tertulis berbasis website mempunyai keunggulan dalam hal: (1) kecepatan, ketepatan, dan efisiensi waktu, (2) tidak ada batasan waktu dan tempat bagi setiap siswa untuk mengakses informasi/tes, (3) ujian dapat dilaksanakan secara online, mulai dari menjawab soal ujian, hingga pemberian penilaian, (4) tampilan tes dapat di-setting lebih menarik, (5) dapat merangsang timbulnya semacam dialog secara tidak langsung antara guru dan siswa. Tawaran yang diberikan oleh teknologi ini adalah kecepatan dan tidak terbatasnya waktu dan tempat untuk mengakses informasi. Kegiatan latihan mengerjakan soal-soal dapat dengan mudah dilakukan oleh para siswa kapan saja dan dimana saja dirasakan aman oleh para siswa tersebut. Batas waktu, ruang, dan jarak tidak lagi menjadi masalah yang rumit untuk dipecahkan. Terjadinya perbedaan ratarata skor hasil belajar, karena siswa yang diberikan tes formatif tertulis berbasis website dapat secara langsung mengatahui skor tes formatifnya serta pembahasannya secara otomatis di website itu. Peluang untuk self remidial yang lebih luas berdampak pada keaktifan siswa untuk memperbaiki kekurangan-kekurangan pada pokok bahasan/topik materi pelajaran yang telah di berikan tes formatif itu. Oleh karena itu, pemberian tes formatif tertulis berbasis website dapat meningkatkan hasil belajar fisika siswa.

2. Terjadi Pengaruh Interaksi Antara Pemberian Tes Formatif Tertulis Berbasis Website, Pemberian Tes Formatif Tertulis Berbasis Paper and Pencil dan Tingkat Pengetahuan Awal Siswa terhadap Hasil Belajar Fisika Siswa

Temuan data penelitian secara empiris diperoleh adanya pengaruh interaksi antara pemberian tes formatif tertulis berbasis website, pemberian tes formatif tertulis berbasis paper and pencil, dan tingkat pengetahuan awal siswa terhadap hasil belajar fisika siswa. Terjadinya pengaruh interaksi disebabkan adanya perbedaan perlakuan dan tingkat pengetahuan awal siswa. Dengan demikian apabila kelompok siswa mempunyai tingkat pengetahuan awal tinggi diberikan tes formatif tertulis yang berbeda, maka hasil belajar fisikanya juga berbeda. Begitu juga sebaliknya pada kelompok siswa yang memiliki tingkat pengetahuan awal rendah apabila diberikan tes formatif tertulis yang berbeda, maka hasil belajar fisikanya juga berbeda. Berdasarkan hasil penelitian yang lain bahwa pengembangan e-modul berbasis web pada materi listrik statis dan listrik dinamis dapat digunakan sebagai multimedia pembelajaran dan dapat meningkatkan pencapaian kompetensi pengetahuan peserta didik (Solihudin, 2018).

3. Pada Kelompok Siswa yang Memiliki Tingkat Pengetahuan Awal Tinggi, Hasil Belajar Fisika Kelompok Siswa yang Diberikan Tes Formatif Tertulis Berbasis Website Lebih Tinggi Dibanding Dengan Kelompok Siswa yang Diberikan Tes Formatif Secara Tertulis Berbasis Paper and Pencil.

Berdasarkan analisa data hasil penelitian secara eksperimen, ditemukan perbedaan hasil belajar fisika pada kelompok siswa yang memiliki tingkat pengetahuan awal tinggi. Kelompok siswa yang memiliki tingkat pengetahuan awal tinggi diberikan tes formatif tertulis berbasis 
website hasil belajar fisikanya lebih tinggi dibanding kelompok siswa yang diberikan tes formatif tertulis berbasis paper and pencil. Terjadinya perbedaan hasil belajar ini, karena kelompok siswa yang diberikan tes formatif tertulis berbasis website dapat mengakses tes kapan saja dan dimana saja tanpa dibatasi oleh waktu dan ruang, mempunyai kesempatan yang luas untuk self-remidial, bisa langsung mengetahui perolehan skor hasil tesnya, dan timbulnya tantangan bagi diri setiap siswa untuk mengulangi tesnya. Demikian juga sebaliknya, kelompok siswa yang memiliki tingkat pengetahuan awal tinggi diberikan tes formatif tertulis berbasis paper and pencil, hasil belajar fisikanya cenderung rendah. Hal ini disebabkan, penilaian formatif tertulis berbasis paper and pencil kurang menimbulkan motivasi bagi siswa. Hal ini sesuai dengan hasil penelitian Sulihin B. Sjukur, bahwa: (1) terdapat perbedaan motivasi belajar antara siswa yang diajarkan pembelajaran blended learning dibandingkan siswa yang diajarkan pembelajaran konvensional; (2) terdapat perbedaan hasil belajar antara siswa yang diajarkan pembelajaran blended learning dibandingkan siswa yang diajarkan pembelajaran konvensional; (3) ada peningkatan motivasi belajar siswa akibat penerapan pembelajaran blended learning; (4) ada peningkatan hasil belajar siswa akibat penerapan pembelajaran blended learning (Sjukur, 2012).

4. Pada Kelompok Siswa yang Memiliki Tingkat Pengetahuan Awal Rendah, Hasil Belajar Fisika Kelompok Siswa yang Diberikan Tes Formatif Tertulis Berbasis Website Lebih Rendah Dibanding Dengan Kelompok Siswa yang Diberikan Tes Formatif Secara Tertulis Berbasis Paper and Pencil.

Hasil analisis data yang diperoleh dari penelitian ini, didapatkan bahwa pada kelompok siswa yang memiliki tingkat pengetahuan awal rendah terjadi perbedaan hasil belajar siswa yang tidak signifikan. Hasil belajar pada kelompok ini, kelompok siswa yang diberikan tes formatif tertulis berbasis paper and pencil, hasil belajar fisikanya sedikit lebih tinggi dibandingkan dengan kelompok siswa yang diberikan tes formatif tertulis berbasis website. Hal ini terjadi karena tingkat pengetahuan awal siswa tidak sebanding dengan tingkat perkembangan teknologi informasi dan komunikasi, atau dengan kata lain bahwa tingkat pengetahuannya kurang mendukung untuk mengaplikasikan teknologi informasi, termasuk website. Selain dari itu, biasanya siswa yang mempunyai tingkat pengetahuan awal rendah cenderung kurang menyukai bentuk tes yang membangkitkan tantangan yang lebih tinggi. Dengan kata lain, tantangan yang disukainya biasanya tantangan yang sesuai dengan tingkat pengetahuan awalnya. Sehingga dengan demikian, kelompok siswa yang memiliki tingkat pengetahuan awal rendah lebih cocok diberikan tes formatif tertulis berbasis paper and pencil. Berdasarkan hasil penelitian, bahwa pada test Potensi Akademik Pascasarjana yang menggunakan test CBT (Computer Based Test) dan PPT (Paper And Pencil Test) memiliki kesetaraan dalam beberapa property psikometrinya yang meliputi taraf kesulitan butir, dan tingkap ketepatan model meskipun secara strukrur pengukuran tes berbentuk CBT belum terdukung secara kuat seperti test berbentuk PPT (Marastuti et al., 2019). Sementara hasil penelitian lain yang relevan dinyatakan bahwa pembelajaran berbasis website dengan menggunakan e-learning meliki kelebihan yaitu menghemat waktu dan hemat biaya (Amin, 2017).

\section{KESIMPULAN}

Berdasarkan hasil pengujian hipotesis dan pembahasan hasil penelitian, maka diperoleh beberapa temuan sebagai berikut: (1) Secara keseluruhan, hasil belajar fisika kelompok siswa yang diberikan tes formatif tertulis berbasis website lebih tinggi dari kelompok siswa yang diberikan tes formatif tertulis paper and pencil. Temuan ini dapat diketahui bahwa pemberian tes formatif tertulis berbasis website memberikan pengaruh yang signifikan terhadap hasil belajar fisika dibandingkan dengan pemberian tes formatif secara tertulis paper and pencil; (2) Terdapat pengaruh interaksi antara pemberian tes formatif tertulis dan tingkat pengetahuan awal terhadap hasil belajar fisika siswa. Temuan in dapat diketahui pula bahwa pemberian tes 
formatif tertulis yang tepat dan dengan memperhatikan tingkat pengetahuan awal siswa memberikan pengaruh yang signifikan terhadap hasil belajar fisika; (3) Pada kelompok siswa yang mempunyai tingkat pengetahuan awal tinggi, hasil belajar fisika siswa yang diberikan tes formatif tertulis berbasis website lebih tinggi dari siswa yang diberikan tes formatif secara tertulis paper and pencil. Temuan ini dapat diketahui bahwa pemberian tes formatif tertulis berbasis website memberikan yang signifikan terhadap hasil belajar fisika pada kelompok siswa yang memiliki tingkat pengetahuan tinggi dibandingkan dengan pemberian tes formatif tertulis paper and pencil; dan (4) Pada kelompok siswa yang mempunyai tingkat pengetahuan awal rendah, hasil belajar fisika siswa yang diberikan tes formatif tertulis berbasis paper and pencil lebih tinggi dari siswa yang diberikan tes formatif secara tertulis berbasis website. Temuan ini didasarkan hasil penelitian yang menunjukkan bahwa pemberian tes formatif tertulis paper and pencil memberikan pengaruh yang tidak signifikan terhadap hasil belajar fisika pada kelompok siswa yang memiliki tingkat pengtetahuan awal rendah dibandingkan dengan pemberian tes formatif tertulis berbasis website. Berdasarkan temuan-temuan di atas maka dapat disimpulkan bahwa pemberian tes formatif tertulis berbasis website berpengaruh terhadap peningkatan hasil belajar fisika.

\section{DAFTAR PUSTAKA}

Aiken, Lewis R. 1996. Rating Scales \& Checklist : Evaluating Behavior Personality, and Attitude. New York: John Wiley \& Sons Inc.

Arikunto, Suharsimi. 2009. Dasar-Dasar Evaluasi Pendidikan. Jakarta: PT. Bumi Aksara.

Amin, Akhmad Kholiqul Amin. (2017). Kajian Konseptual Model Pembelajaran Blended Learning berbasis Web untuk Meningkatkan Hasil Belajar dan Motivasi Belajar. Bojonegoro: Jurnal Pendidikan Edutama, Vol. 4, No. 2, Juli 2017.

Asrul, et al, 2010. Evaluasi Pembelajaran. Bandung: Citapustaka Media.

Djaali dan Pudji Muljono. 2008. Pengukuran dalam Bidang Pendidikan. Jakarta: PT. Grasindo.

Djaali. 2010. Konsep Dasar dan Pokok-Pokok Desain Eksperimen. Jakarta: Program Pascasarjana Universitas Negeri Jakarta.

Kadir. 2010. Statistika Untuk Penelitian Ilmu-ilmu Sosial. Jakarta: PT. Rosemata Sempurna.

Kujawa, Stephen T. dan L. Huske. The Strategic Teaching and Reading Project Guidebook. http://www.ncrel.org/sdrs/areas/issues/students/learning/lr1pk.htm (diakses 16 Oktober 2010).

Marastuti, Ariana, et al. (2019). Perbandingan Properti Psikometri antara Tes PAPs Berbentuk Computer-Based dan Paper and Pencil Test. Yogyakarta: Gadjahmada Journal Of Psychology, Volume 6, No. 1, 2020:12-28.

Patta, Abd. Rahman, et al. (2020) Kajian Perbandingan Hasil Nilai Pengujian Berbasis Kertas dan Berbasis Komputer Sebagai Indikator Mengukur Kesiapan Peserta Tes Menghadapi Ujian Berbasis Komputer. Makasar: Jurnal Media TIK, Vol. 3 No. 3, September 2020

Solihudin JH, Taufik. (2018). Pengembangan E-Modul Berbais Web untuk Meningkatkan Pencapaian Kompetensi Pengetahuan Fisika Materi Listrik Statis dan Dinamis di SMA. Bandung: Jurnal Wahana Pendidikan Fisika, Vol. 3, No. 2, 2018: 51-61

Sjukur, Sulihin B. (2012). Pengaruh Blended Learning Terhadap Motivasi Belajar dan hasil Belajar Siswa Tingkta SMK. Yogyakarta: Jurnal Pendidikan Vokasi, Vol. 2 Nomor 3, November 2012. 